\title{
Uji Aktivitas Ekstrak Etanol Daun Lidah Buaya (Aloe Vera) Terhadap Penghambatan Pertumbuhan Staphylococcus aureus Dan Candida albicans
}

\author{
Gemy Nastiti Handayani ${ }^{1}$ \\ ${ }^{1}$ Program Studi Farmasi UIN Aluddin Makassar \\ ${ }^{1}$ Email: gemynastity75@gmail.com
}

\begin{abstract}
Abstrak: Penelitian ini bertujuan untuk mengetahui aktivitas ekstrak etanol daun lidah buaya (Aloe vera) terhadap bakteri Staphylococcus aureus dan jamur Candida albicans. Ekstraksi daun lidah buaya dilakukan dengan metode maserasi, kemudian dibuat beberapa konsentrasi ekstrak yaitu 2,5\%, 3,5\%, dan 4,5\% untuk bakteri Staphylococcus aureus dan konsentrasi 4\%, 8\% dan 12\% untuk jamur Candida albicans. Pengujian daya hambat dilakukan dengan metode difusi agar. Hasil pengujian menunjukkan bahwa ekstrak etanol daun lidah buaya (Aloe vera) memiliki aktivitas antibakteri Staphylococcus aureus dan anti jamur Candida albicans yang ditandai dengan adanya zona bening. Pada bakteri Staphylococcus aureus memberikan zona hambat optimum pada konsentrasi $4,5 \%$ dengan diameter 10,8 mm sedangkan pada, jamur Candida albicans memberikan zona hambat optimum pada konsentrasi $12 \%$ dengan diameter hambatan 18,87 mm.
\end{abstract}

\section{Kata Kunci: Etanol, Daun Lidah Buaya, Staphylococcus aureus, Candida albicans}

\begin{abstract}
This study aims to determine the activity of ethanol extract of Aloe vera leaves against Staphylococcus aureus bacteria and Candida albicans fungi. Extraction of aloe vera leaves is done by maceration method, then extracted several concentrations, namely $2.5 \%, 3.5 \%$, and $4.5 \%$ for Staphylococcus aureus bacteria and concentrations of $4 \%, 8 \%$ and $12 \%$ for Candida albicans fungi. The inhibitory testing is done by agar diffusion method. The test results showed that the ethanol extract of Aloe vera leaves had antibacterial activity of Staphylococcus aureus and anti-fungal Candida albicans which was characterized by the presence of a clear zone. In Staphylococcus aureus bacteria provide optimum inhibition zone at a concentration of $4.5 \%$ with a diameter of $10.8 \mathrm{~mm}$ while in, the fungus Candida albicans provides the optimum inhibition zone at a concentration of $12 \%$ with a diameter of resistance $18.87 \mathrm{~mm}$.
\end{abstract}

Key Words: Ethanol, Aloe vera leaves, Staphylococcus aureus, Candida albicans

Indonesia merupakan salah satu pusat keanekaragaman hayati dunia. Dari Sabang sampai Merauke tersebar sekitar 40.000 jenis tumbuhan yang mengandung berbagai jenis bahan kimia yang berpotensi sebagai bahan pangan, kosmetika dan obat-obatan (Agusta, 2000). Obat tradisional kembali populer dipilih sebagai obat untuk menyembuhkan berbagai

BIOLOGI SEL (VOL 8 NO 1 EDISI JAN-JUN 2019 ISSN 2252-858X/E-ISSN 2541-1225) PAGE 1 
penyakit karena disamping harganya terjangkau, tanpa efek samping khasiatnya juga menjanjikan. Obat tradisional adalah obat dari alam yang telah digunakan secara turun temurun. Sehingga cara, takaran, lama penggunaan, khasiat dan penggunaannya telah diketahui berdasarkan penuturan nenek moyang. Obat tradisional sebagai sarana perawatan kesehatan, memperkuat daya tahan tubuh dan untuk menanggulangi berbagai macam penyakit sudah berakar dalam kehidupan masyarakat Indonesia (Hargono, 1997).

Obat-obat tradisional yang digunakan untuk pengobatan harus mampu mempunyai efek terapi, sehingga dapat dipertanggung jawabkan penggunaannya. Akan tetapi pembuktian ilmiah mengenai khasiat dan pengawasan efek samping obat tradisional belum banyak dilakukan (Syamsu hidayat dan Hutapea, 1991). Penggunaan tanaman obat sebagai alternatif dalam pengobatan untuk masyarakat semakin meningkat, sehingga diperlukan penelitian untuk membuktikan khasiat tanaman obat tersebut. Pengalaman sebelumnya telah membuktikan bahwa untuk beberapa penyakit, ternyata pengobatan herba lebih efektif memberikan solusi penyembuhan dibanding dengan pengobatan menggunakan bahan kimia. Keunggulan pengobatan herba terletak pada bahan dasarnya yang bersifat alami sehingga efek sampingnya dapat ditekan seminimal mungkin (Agromedi, 2008).

Salah satu tanaman obat berkhasiat adalah Aloe vera atau yang lazim disebut lidah buaya. Pada zaman Cleopatra, lidah buaya dimanfaatkan untuk bahan baku kosmetik. Bangsa Arab telah lama memanfaatkan tanaman yang dijuluki "the miracle plant" tersebut untuk pengobatan dan bahan kosmetik. Demikian halnya dengan bangsa Yunani dan Romawi, mereka menggunakan lidah buaya untuk mengatasi berbagai masalah kesehatan. Lidah buaya (Aloe vera) adalah salah satu tanaman obat tradisional yang termasuk dalam suku Liliaceae, sering ditanam dipot atau halaman rumah. Hanya saja khasiatnya belum digunakan secara optimal, padahal lidah buaya ini mengandung berbagai zat aktif yang dapat menyembuhkan berbagai penyakit, khasiat yang sudah dikenal dari tanaman ini yaitu hanya sebagai penyubur rambut dan memperhalus kulit. (Furnawanthi, 2002). Lebih lanjut Furnawanthi (2002) menyatakan bahwa lidah buaya adalah tanaman yang semua bagiannya bermanfaat. Pelepah lidah buaya dapat dikelompokkan menjadi 3 bagian yang dapat digunakan untuk pengobatan, antara lain daun, keseluruhan daunnya dapat digunakan secara langsung atau dalam bentuk ekstrak. Eksudat adalah getah berbentuk kental berwarna kuning dan rasanya pahit, kemudian gel merupakan bagian yang berlendir yang diperoleh dengan cara menyayat bagian dalam daun. Lidah buaya bersifat antibiotik, antiseptik, antibakteri, antikanker, antivirus, anticendawan, antiinfeksi, antiradang, antipembengkakan, antiaterosklerosis, antivirus, antiinflamasi dan laksatif (Dalimartha, 2000).

Staphylococcus aureus adalah patogen utama pada manusia. Hampir setiap orang pernah mengalami berbagai infeksi $S$. aureus selama hidupnya, dari keracunan makanan berat atau infeksi kulit yang kecil, sampai infeksi yang tidak bisa disembuhkan (Jawetz, 
2001). Infeksi oleh jenis kuman ini yang terutama menimbulkan penyakit pada manusia. Setiap jaringan atau pun alat tubuh dapat diinfeksi olehnya dan menyebabkan timbulnya penyakit dengan tanda-tanda yang khas, yaitu peradangan, nekrosis, dan pembentukan abses. Infeksinya dapat berupa furunkel yang ringan pada kulit sampai piemia yang fatal (Chatim, 1994). Candidiasis adalah mikosis yang menyerang kulit atau jaringan yang lebih dalam lagi. Penyebabnya adalah Candida albicans. Jamur ini sering kali terdapat pada mukosa mulut. Candidiasis dapat mengenai kulit, kuku atau organ tubuh seperti ginjal, jantung, dan paru-paru. Candidiasis dapat pula terjadi pada selaput lendir mulut dan vagina.

Stomatitis aphtosa atau sariawan adalah radang yang terjadi di daerah mukosa mulut, biasanya berupa bercak putih kekuningan dengan permukaan yang agak cekung, bercak itu dapat berupa bercak tunggal maupun kelompok. Stomatitis aphtosa atau sariawan atau dalam bahasa kerennya oral thrush merupakan penyakit yang diakibatkan dengan adanya jamur pada mulut dan saluran kerongkongan. Jamur yang sekarang lebih dikenal dengan sebutan Candida albicans bukanlah jamur yang aneh dan berbahaya. Hampir di setiap jengkal tubuh kita mengandung jamur ini termasuk di daerah mukosa mulut dan alat kelamin, namun adanya jamur ini tidak menimbulkan keluhan yang berarti, (Jawetz, 1986).

Lidah buaya (Aloe vera) merupakan tanaman hortikultura yang berasal ari Kepulauan Canary di sebelah barat Afrika. Pada abad XVII, tanaman ini mulai dikenal di India dan kemudian menyebar ke negara tropika lainnya, termasuk Indonesia. Tanaman lidah buaya dikenal dengan nama lidah buaya, di Inggris dikenal dengan Crocodiles Tongues dan di Malaysia dikenal dengan nama Jadam, sedangkan di Latin, Portugis, Perancis dan Jerman dikenal dengan nama Aloe. Selain itu di Cina lidah buaya dikenal dengan nama Lu hiu, di Spanyol dengan nama Jelly Leek, di Indian dengan nama Ailwa, di Arab dengan nama Sabbar serta di Filipina dikenal dengan nama Natau, (Furnawanthi, 2002). Kandungan Kimia pada daun lidah buaya (Aloe vera) adalah lignin, saponin, Kompleks Antraguinone, Acemannan, Enzim bradykinase, Karbiksipeptidase, Glukomannan, Mukopolysakarida, Tennin, aloctin A, Salisilat, Asam amino, Mineral, Vitamin A, B $1, B_{2}, B_{6}, B_{12}$, C, E, Asam folat, (Furnawanthi, 2002).

\section{METODE PENELITIAN}

Metode pengerjaan dalam penelitian ini terbagi menjadi 2 diantaranya pembuatan ekstrak etanol untuk uji bakteri dan ekstrak etanol untuk uji jamur. Untuk uji bakteri, ekstrak etanol yang diperoleh kemudian dibuat dalam konsentrasi 2,5\%, 3,5\% dan 4,5\% b/v. Untuk konsentrasi 2,5\% ditimbang 0,25 g ekstrak etanol kemudian dilarutkan dengan etanol sebanyak $10 \mathrm{ml}$, konsentrasi 3,5\% ditimbang $0,35 \mathrm{~g}$ ekstrak etanol kemudian dilarutkan dengan etanol sebanyak $10 \mathrm{ml}$. Untuk konsentrasi 4,5\% ditimbang 0,45 g ekstrak etanol kemudian dilarutkan dengan etanol sebanyak $10 \mathrm{ml}$. Untuk uji jamur, 
ekstrak etanol yang diperoleh kemudian dibuat dalam konsentrasi 4\%, $8 \%$ dan $12 \% \mathrm{~b} / \mathrm{v}$. Untuk konsentrasi $4 \%$ ditimbang 0,4 g ekstrak etanol kemudian dilarutkan dengan etanol sebanyak $10 \mathrm{ml}$. Untuk konsentrasi $8 \%$ ditimbang $0,8 \mathrm{~g}$ ekstrak etanol kemudian dilarutkan dengan etanol sebanyak $10 \mathrm{ml}$. Untuk konsentrasi 12\% ditimbang 1,2 g ekstrak etanol kemudian dilarutkan dengan etanol sebanyak $10 \mathrm{ml}$.

\section{HASIL DAN PEMBAHASAN}

Hasil pengujian aktivitas ekstrak etanol daun lidah buaya (Aloe vera) terhadap bakteri Staphylococcus aureus dan jamur Candida albicans dapat dilihat pada Tabel 1 dan 2 di bawah ini.

Tabel 1. Hasil uji aktivitas ekstrak etanol daun lidah buaya (Aloe vera) terhadap bakteri Staphylococcus aureus

\begin{tabular}{cc}
\hline Konsentrasi Sampel & Diameter Zona Hambatan $(\mathrm{mm})$ \\
\cline { 2 - 2 } & Staphylococcus aureus \\
\hline $2,5 \%$ & 8,6 \\
$3,5 \%$ & 9,98 \\
$4,5 \%$ & 10,8
\end{tabular}

Tabel 2. Hasil uji aktivitas ekstrak etanol daun lidah buaya (Aloe vera) terhadap bakteri jamur Candida albicans

\begin{tabular}{cc}
\hline Konsentrasi Sampel & Diameter Zona Hambatan $(\mathrm{mm})$ \\
\cline { 2 - 2 } $4 \%$ & Candida albicans \\
\cline { 2 - 2 } $8 \%$ & 11,87 \\
$12 \%$ & 16,09 \\
18,87 \\
\hline
\end{tabular}

Lidah buaya (Aloe vera) dikenal sebagai tanaman yang memiliki banyak manfaat karena semua bagian dari tanaman ini dapat dimanfaatkan baik untuk perawatan tubuh maupun untuk mengobati berbagai penyakit. Dimana pelepah lidah buaya dapat dikelompokan menjadi 3 bagian yang dapat digunakan untuk pengobatan, antara lain daun, keseluruhan daunnya dapat digunakan baik secara langsung atau dalam bentuk ekstrak, kemudian eksudat, adalah getah yang keluar dari dalam saat dilakukan pemotongan, eksudat ini berbentuk kental berwarna kuning, dan rasanya pahit. Kemudian gel, adalah bagian yang berlendir yang diperoleh dengan cara menyayat bagian dalam daun (Fumawanthi, 2003). Didalam gel lidah buaya ini dipercaya mengandung berbagai zat aktif dan enzim yang sangat berguna untuk menyembuhkan berbagai penyakit. Karena kandungan zat aktif dan enzim inilah maka sifat gel ini sangat sensitif terhadap suhu, udara dan cahaya, serta sangat mudah teroksidasi, dan gel akan mudah berubah warna menjadi kuning hingga coklat.

Penelitian ini menggunakan 200 gram daun lidah buaya (Aloe vera) yang dimaserasi dengan etanol $96 \%$ sehingga diperoleh ekstrak kental sebanyak 15,216 g. Metode yang digunakan untuk menghambat pertumbuhan bakteri Stapylococcus aureus

BIOLOGI SEL (VOL 8 NO 1 EDISI JAN-JUN 2019 ISSN 2252-858X/E-ISSN 2541-1225) PAGE 4 
dan jamur Candida albicans adalah metode difusi agar dengan menggunakan paper disc dan menggunakan medium NA untuk bakteri dan PDA untuk jamur. Metode ini digunakan untuk mengetahui besarnya diameter hambatan yang terbentuk pada bakteri Stapylococcus aureus dan jamur Candida albicans, setelah masa inkubasi akan terjadi proses difusi senyawa antibakteri dan anti jamur yang terkandung dalam ekstrak etanol daun lidah buaya (Aloe vera) ke dalam gel agar sehingga akan menghambat pertumbuhan bakteri dan jamur pada medium dan membentuk zona bening disekitar paper disc. Zona inilah yang diukur diamaternya dengan jangka sorong.

Hasil penelitian menunjukkan bahwa ekstrak etanol daun lidah buaya (Aloe vera) dengan konsentrasi 2,5\%, 3,5\%, 4,5\% untuk bakteri dapat menghambat pertumbuhan bakteri Stapylococcus aureus dan konsentrasi 4\%, 8\%, dan 12\% untuk menghambat pertumbuhan jamur Candida albicans. Hal ini diduga disebabkan karena adanya senyawa kimia saponin dan acemannan yang bersifat antiseptik, antibiotik, anti bakteri dan anti jamur terkandung dalam lidah buaya (Aloe vera). Dimana senyawa Saponin dapat bekerja sebagai antimikroba. Senyawa saponin akan merusak membran sitoplasma dan membunuh sel. dan acemannan merupakan senyawa karbohidrat yang akan mengaktifkan makrofag sehingga menyebabkan terjadinya fagositosis, (Furnawanti, 2004). Dari hasil pengukuran diameter hambatan untuk bakteri dan jamur uji, terjadi perbedaan konsentrasi diameter hambatan. Pada uji bakteri Staphylococcus aureus dengan konsentrasi 2,5\% masa inkubasi 24 jam, zona penghambatan berdiameter $8,6 \mathrm{~mm}$. Pada perlakuan konsentrasi 3,5 \% dengan masa inkubasi 24 jam, zona penghambatan berdiameter 9,98 $\mathrm{mm}$. Pada perlakuan konsentrasi 4,5\% dengan masa inkubasi 24 jam, zona penghambatan berdiameter 10,8 mm. Sedangkan untuk uji jamur Candida albicans pada perlakuan konsentrasi $4 \%$ dengan masa inkubasi 3x24 jam, zona penghambatan berdiameter 11,86 mm. Pada perlakuan konsentrasi $8 \%$ dengan masa inkubasi $3 \times 24$ jam, zona penghambatan berdiameter $16,09 \mathrm{~mm}$. Pada perlakuan konsentrasi $12 \%$ dengan masa inkubasi 3x24 jam, zona penghambatan berdiameter 18,87 mm.

Hal ini menunjukkan bahwa semakin meningkatnya konsentrasi maka hambatannya semakin besar. Semakin tinggi konsentrasi ekstrak maka semakin tinggi pula kadar senyawa zat aktif yang terlarut didalam ekstrak. Setelah diperoleh diameter hambatan dari bakteri uji dan jamur uji, kemudian dilakukan perhitungan secara statistik untuk menentukan konsentrasi optimum ekstrak bakteri dan jamur uji dengan menggunakan rancangan acak lengkap (RAL). Penggunaan metode RAL karena metode ini paling umum digunakan untuk kondisi alat, bahan, media, dan lingkungan yang homogen seperti yang ada di laboratorium.

Dari hasil analisis uji aktivitas ekstrak etanol daun lidah buaya (Aloe vera) terhadap bakteri Staphylococcus aureus dan jamur Candida albicans didapatkan nilai $\mathrm{F}_{\text {Hitung }}>\mathrm{F}_{\text {Tabel }}$ pada taraf uji $\alpha=0,01$ dan $\alpha=0,05$ yang menunjukkan bahwa ada konsentrasi yang diameternya sangat menonjol dibandingkan dengan konsentrasi yang 
lain. Untuk bakteri Staphylococcus aureus diperoleh nilai koefisien keragaman (KK) 4,822\%, kemudian dilanjutkan dengan Uji Beda Nyata Jujur (BNJ). Sedangkan untuk jamur Candida albicans diperoleh nilai koefisien keragaman (KK) 6,274\%, kemudian dilanjutkan dengan Uji Beda Nyata Terkecil (BNT).

Untuk uji aktivitas daun lidah buaya (Aloe vera) terhadap bakteri Staphylococcus aureus dengan menggunakan uji beda nyata Jujur (BNJ) menunjukkan bahwa pengaruh konsentrasi terhadap diameter hambatan berbeda nyata / sangat nyata antara konsentrasi yang satu dengan konsentrasi yang lain. Dari hasil uji tersebut menunjukkan bahwa konsentrasi optimum yaitu pada konsentrasi 4,5\% dengan diameter 10,8 mm. Untuk uji aktivitas daun lidah buaya (Aloe vera) terhadap jamur Candida albican dengan menggunakan uji beda nyata terkecil (BNT) menunjukkan bahwa pengaruh konsentrasi terhadap diameter hambatan berbeda nyata / sangat nyata antara konsentrasi yang satu dengan konsentrasi yang lain. Dari hasil uji tersebut menunjukkan bahwa konsentrasi optimum yaitu pada konsentrasi $12 \%$ dengan diameter $18,78 \mathrm{~mm}$.

\section{KESIMPULAN}

Berdasarkan penelitian yang telah dilakukan maka dapat disimpulkan bahwa : (1) Ekstrak etanol daun lidah buaya (Aloe vera) dapat menghambat pertumbuhan bakteri Staphylococcus aureus dan jamur Candida albicans. (2) Ekstrak etanol daun lidah buaya (Aloe vera) dapat menghambat pertumbuhan bakteri Staphylococcus aureus pada konsentrasi optimum yakni 4,5\% dan menghambat pertumbuhan jamur Candida albicans pada konsentrasi optimum yakni $12 \%$.

\section{DAFTAR PUSTAKA}

Agusta. (2000). Minyak Atsiri Tumbuhan Tropika Indonesia. ITB. Bandung.

Anonim. (1989). Material Medika Kesehatan Indonesia. Jilid 5. Dirjen POM. Departemen Kesehatan RI: Jakarta

Anonim. (1985). Tanaman Obat Indonesia. Jilid I. Direktorat Jendral Pengawasan Obat dan Makanan Departeman Kesehatan Republik Indonesia. Jakarta: 43

Bonang G, Koeswardono ES. (1982.) Mikrobiologi Kedokteran untuk Laboratorium dan Klinik. Jakarta: Grainedia

Chantin, A. dan Suharto. (1994). Sterilisasi dan Disinfeksi dalam Mikrobiologi Kedokteran, Edisi Revisi, Binarupa Aksara, Jakarta Dalimartha, Setiawan. 2000. Atlas Tumbuhan Obat Indonesia. Jilid 2, Trubus Agriwidya, Jakarta.

Dalimartha, Setiawan. (2000). Atlas Tumbuhan Obat Indonesia. Jilid 2, Trubus Agriwidya, Jakarta.

Departemen Kesehatan RI. (1986). Sediaan Galenik. Jakarta, hal 7- 23.

Depkes. (1979). Farmakope Indonesia, Edisi III. Departemen Kesehatan Republik Indonesia, Jakarta. 
Djide, N. (2008). Dasar-Dasar Mikrobiologi Farmasi. Makassar: Lembaga Penerbitan Universitas Hasanuddin, hal 340-342.

Djide, N dan Sartini. (2007). Penuntun Praktikum Mikrobiologi Farmasi Dasar. Makassar: Laboratorium Mikrobiologi dan Bioteknologi Farmasi Universitas Hasanuddin, hal 19-22, 82.

Djide, N. (2006). Analisis Mikrobiologi Farmasi. Makassar: Laboratorium Mikrobiologi Farmasi Fakultas Matematika Dan Ilmu Pengetahuan Alam Universitas Hasanuddin, hal 134-142.

Field, A dan Longman, L (2003). Tyldesley's Oral Medicine. Ed. Ke-5. Oxford University Press, hal 52-58.

Fitriana, S. Ema H. Tenny S. (2005). EfektifitasPemberiaan Gel Lidah Buaya (Aloe vera) Secara Topikal Pada Stomatitis Aphtousa Minor (sariawan). Lembaga penelitian. Unpad.

Fuerst R. Frobisher and Fuerst's. (1983). Microbiologi In Health and Disease (14th edn). Blackwell Scientific Publications. Oxford. London.

Furnawanthi, I. (2002). Khasiat \& Manfaat Lidah Buaya Si Tanaman Ajaib. Agro Media Pustaka. Jakarta. Hal 1-21.

Gibson, J. M. (1996). Mikrobiologi dan Patologi Modern Untuk Perawat, 1.6.EGC; Jakarta.

Greenberg. M.S.D.D.S dan Glick M. (2003). Burket's Oral Medicine Diagnosis \& Treatment. Ed. Ke-10. BC Decker Inc. New Jersey. Hal 63-65.

Hariana, Arief. (2000). Tumbuhan Obat \& Khasiatnya. Seri 3. PT. Niaga Swadaya. Jakarta.

Jawetz, E., Melnick, J. L., dan Adelberg, E. A. (2001). Mikrobiologi Kedokteran Edisi XXII. Diterjemahkan oleh Bagian Mikrobiologi Fakultas Kedokteran Universitas Airlangga. Penerbit Salemba Medika. Jakarta.

Katno, Pramono S. (2008). Tingkat Manfaat dan Keamanan Tanaman Obat Tradisional. Jogjakarta: Fakultas Farmasi UGM.

Kumar, V.MD. Cotrain, R.S. M.D dan Robbius, S.L.M.D. (1997). Basic Pathology. Ed. Ke-6. W.B. Saundeis Company. Hal 45-471.

Pelczar dan Chan. (1989). Dasar-dasar Mikrobiologi I, diterjemahkan oleh Ratna Siri, H. UI-Press. Jakarta

Purbaya J.R. (2003). Mengenal \& Memanfaatkan Khasiat Aloe vera. CV. Pionerjaya. Bandung. Hlm 21-165.

Pratiwi, Sylvia T. (2008). Mikrobiologi Farmasi. Jakarta: Erlangga, hal 188-191.

Sudjana. (2005). Metode Statistika Edisi Ke-VI. Tarsito. Bandung. Hal 9 - 73, 230.

Sutomo, B. (2006). Lidah Buaya memperbaiki Sistem pencernaan, www.yahoo.com.

Tjitrosoepomo, G. (1993). Taksonomi Tumbuhan (Spermatophyta). Gadjah Mada University Press:. Jogjakarta. Hal. 192-3

BIOLOGI SEL (VOL 8 NO 1 EDISI JAN-JUN 2019 ISSN 2252-858X/E-ISSN 2541-1225) PAGE 7 
Tobo, F., 2001. Buku Pegangan Laboratorium Fitokimia I. Laboratorium Fitokimia Jurusan Farmasi Fakultas MIPA, Universitas Hasanuddin. Makassar. 